\title{
In Vivo Imaging of Chemically Engineered Proteins and Cells by Oligosaccharides
}

\author{
化学的に糖鎖修飾を施した人工糖タンパク質や人工細胞によるインビボイメージング
}

Key Words: chemical engineering, in vivo imaging, inflammation and tumor targeting, post-translational modifications

mRNA translates the DNA information to the synthesizing proteins, and the resulting glycoproteins in the endoplasmic reticulun are translocated to the Golgi apparatus, where oligosaccharides are modified to have diverse structures. A whole process called "post-translational modifications (PTMs)", provides glycoproteins with diverse structures and functions. The functions of the proteins are also precisely regulated afterwards through the "processing" of the glycan chains by glycosidases or transferases in response to the various biological environments. Can chemists mimic the glycan-PTMs by use of the synthetic organic chemistry, and can these PTM mimicries be applied to in vivo imaging or targeting? This report describes (1) chemistry-based site-selective modification of proteins by oligosaccharides (chemical post-translational mimicry) and (2) new strategy for tumor targeting by artificial cells, based on the chemical engineering of the cell-surfaces by oligosaccharides.

Davis and co-workers recently succeeded in mimicking the glycan-PTMs of proteins by the chemical methods, and targeting the mouse and rat brain inflammation and disease in vivo [Nature (2007) 446, 1105-1109]. They genetically engineered a target protein in the E-coli system by exchanging the methionine to artificial amino acids containing the azide and/or the acetylene moieties, and subsequently, the $\mathrm{Cu}(\mathrm{I})$ mediated Huisgen cycloaddition reaction (Sharpless/Meldal click reaction) was performed to introduce the glycans and/or other small functional molecules on the specific sites of the protein. Although the $\mathrm{Cu}(\mathrm{I})$-mediated Huisgen cycloaddition requires a few $\mathrm{mg}$ of the protein, more than 1000-times equivalents of $\mathrm{CuBr}$ with high purity $(99.999 \%)$, and excess amount of the quaternary amine as an activator, the mono$\sim$ tetra-saccaharides can be efficiently introduced on the protein. The different functional groups, such as the glycans or the other small organic molecules, could be introduced at two different sites on the same protein, by making use of the disulfide bond formation with cystein residue. Based on their chemistry-based PTM mimicry, in vivo experiments for targeting the P-selectin were performed. By using SS $\beta$ G with LacZ-type galactosidase activity as a protein template, the sialyl Lewis $X$ and the acidic p-toluenesulfonyl group were doubly introduced to the specific sites of the protein,
小胞体において mRNAに沿って翻訳・合成された糖夕 ンパク質は、ゴルジ装置へと運搬され、そこで様々な糖鎖修 飾が施される。この翻訳後糖鎖修飾と呼ばれる一連のプロセ スによって、構造的に、そして機能的にも広範囲の “多様性” を持つ糖タンパク質群が合成される。このプロセスでは、生 体内での環境に応答してグリコシダーゼやトランスフェラー ゼによるプロセッシングや再合成の過程を経て、その機能が 厳密に制御されている。化学者の立場から、糖鎖の翻訳後糖 鎖修飾を有機合成化学で模倣できないか?巳らには模倣した 人工分子を活用して、効率的なインビボイメージングやター ゲティングに応用できないか? と誰もが期待するであろう。 本レポートでは、(1) タンパク質への化学的な位置選択的糖鎖 修飾法 ( 疑似的な化学的翻訳後糖鎖修飾法) を用いた、人工糖 タンパク質による炎症や感染症のターゲティング、および (2) 細胞表層上への化学的糖鎖エンジニアリング法を基盤とした、 人工糖鎖付加細胞による癌組織ターゲティングの新規ストラ テジーを紹介したい。

Davis らは、タンパク質の翻訳後糖鎖修飾を化学法によっ て模倣し、マウスインビボ実験で炎症や感染症をターゲティ ングすることに成功した [Nature (2007) 446, 1105-1109]。彼ら は、メチオニンをアセチレンやアジド基を持つ人工アミノ酸 に変換した遺伝子操作タンパク質を大腸菌内で発現させた後、 これらの官能基に選択的な $\mathrm{Cu}(\mathrm{I})$ 存在下による Huisgen 環化 反応 (Sharpless/Meldal クリック反応) を実施して、位置選択 的な糖鎖導入を可能にした。この際、数ミリグラムのタンパ

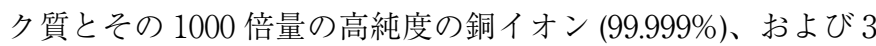
級アミン反応活性化剂が必要であるものの、1 糖から 4 糖まで 様々な糖鎖との反応が水中で良好に進行する。一方、同一夕 ンパク質上のシステイン残基と、糖鎖や低分子誘導体とのジ スルフィド結合形成反応を利用することによって、タンパク 質の 2 カ所に異なった糖鎖 (または低分子化合物) を導入する ことに成功した。この化学的な翻訳後糖鎖修飾法を用いて、Pセレクチンをターゲットとした侵襲的イメージングを実施し た。すなわち、LacZ 型ガラクトシダーゼ活性を持つ SS $\beta$ G 夕 ンパク質をテンプレートとして、計算化学を活用しながら Pセレクチンと相互作用すると予想される位置に対して、シア 
which were expected to interact with the P-selectin, by the help of the computational analysis of the interaction. PTM mimicry thus prepared was then introduced to the interleukin$1 \beta$-induced rat models of cerebral inflammation, and after the dissection, the P-selectin expression in the brain tissues was analyzed by the treatment with the widely used probe $\mathrm{X}-\mathrm{Gal}$; the five-times more sensitive detection could be achieved than the conventional antibody-based methods. The overexpressed cerebral P-selectin could also be detected in the Malaria-infected mouse model (Plasmodium), by using the same chemistry-based PTM mimicry. It is noteworthy that the detection sensitivity of P-selectin could significantly be decreased by removing the sialic acid from the sialyl Lewis $\mathrm{X}$ (simple Lewis $\mathrm{X}$ ), and by utilizing the truncated structures of the sialyl Lewis X, i.e., mono- and di-saccharides. Glycan without fucose in sialyl Lewis X structure, also slightly decreased the targeting efficiency, and the PTM mimicry without the acidic p-toluenesulfonyl group could not target the P-selectin; the results show the importance of PTMs in acquiring the functional diversification by the glycans and/ or the other small molecules, and these were proved by his chemistry-based protocols. Davis's chemistry-based PTMs require the replacement of the methionine and cystein, which are not involved in the subsequent bioorthogonal reactions, to isoleucine or serine as their isosters, and in addition, the $\mathrm{Cu}(\mathrm{I})$-mediated Huisgen cycloaddition should be performed under the harsh conditions; these are not applicable to the more complicated systems, i.e., sensitive proteins and/or the proteins on the cells. In order to circumvent the problems, the same group recently reported the alternative bioconjugation chemistry on the proteins and these to be referred as follows; the conjugation addition of the thioglycosides to the dehydroalanine [J. Am. Chem. Sci. (2008) 130, 5052-5053], the efficient aqueous cross metathesis with thioallyl group through the coordination of the "Ru" catalyst to the sulfur atom [J. Am. Chem. Sci. (2008) 130, 9642-9643], free-radical addition of the thioglycosides to the homoallylalanine [Angew. Chem. Int. Ed. (2009) 48, 7798-7802], and Suzuki-Miyaura cross coupling [J.Am. Chem. Sci. ].

On the other hands, Fukase and Tanaka and co-workers have succeeded in introducing the various fluorophores (for labeling) and $\mathrm{N}$-glycans with the complex structures (for chemical engineering) selectively on the cell surfaces through their $6 \pi$-azaelectrocyclization $[J$. Am. Chem. Soc. (2002) 124, 9660-9661; Angew. Chem. Int. Ed. (2008) 47, 102-105], by treating the cells with the probes at $37{ }^{\circ} \mathrm{C}$ for 10 min under the probe concentration of $10^{-8} \mathrm{M}$ [Chem. Med. Chem.(2010) in press]. The reaction proceeds selectively on the lysine and/or phosphatidylethanolamine, being overexpressed on the surface of the cells; the labeling and/or engineering probes do not internalize in the cells, and therefore, the reaction does
リルルイス $\mathrm{X}$ 糖鎖、および酸性基である $\mathrm{p}-$ トルエンスルフォ ニル誘導体で二重に修飾した。インターロイキン $-1 \beta$ で脳内に 炎症を誘導したラットモデルに対してこの化学的糖鎖修飾夕 ンパク質を導入し、剖検の後、化学発光官能基 $(X)$ を結合させ たX-Gal で染色することによって、従来の抗体を用いる方法 と比較して 5 倍の P - セレクチン検出感度を実現した。一方、 この化学的糖鎖修飾タンパク質を用いることによって、Plas modium に感染したマラリア感染マウスモデルの脳内 P- セレク チン過剩発現部位を検出することにも成功している。この際、 シアリルルイス Xからシアル酸を除いた糖鎖、または単糖や 2 糖では、P-セレクチンの検出感度が著しく低下する。また、 フコースのみを除去した糖鎖を用いても、ターゲティングの 効率が多少低下することは興味深い。さらに、酸性の官能基 である $\mathrm{p}$-トルエンスルフォニル誘導体を除いた糖鎖修飾タン パク質では、P-セレクチンを全く検出できなかったことより、 翻訳後糖鎖 (または低分子) 修飾によるタンパク質の多様性獲 得の重要性を化学法によって模倣し、証明した例として、特 筆すべき研究である。本法は、糖鎖や低分子修飾に関与しな いメチオニンやシステインをそのアイソスターであるイソロ イシンやセリンに置換しなければならないこと、また、修飾 の反応条件が過酷であることが、より複雑な系へと展開する 上で問題となる。最近、同グループによってデヒドロアラニ ンに対するチオグリコシドの共役付加反応 $[J . A m$. Chem. Sci (2008) 130, 5052-5053]、ルテニウム触媒の硫黄原子への配位に よる新規な反応活性化効果を用いたチオアリル基へのクロス メタセシス反応 [J.Am. Chem.Sci. (2008) 130,9642-9643]、ホモ アリルアラニンに対するチオグリコシドのフリーラジカル付 加反応 [Angew. Chem. Int. Ed. (2009) 48, 7798-7802]、または鈴 木 - 宮浦反応 [J.Am. Chem. Sci. (2009) 131, 16346-16347] を経た タンパク質への新しい糖鎖導入法を次々と報告しているので、 ご参考頂きたい。

一方、深瀬・田中らは、独自に開発した高速 $6 \pi$-アザ電子 環状反応 [J. Am. Chem. Soc. (2002) 124, 9660-9661; Angew. Chem. Int. Ed. (2008) 47，102-105] を用いることにより、10-8 $\mathrm{M}$ という極低濃度のプローブを細胞に $37{ }^{\circ} \mathrm{C}$ で 10 分間作用さ せるだけで、表層にのみ選択的に蛍光基 (標識化) や複雑な構 造を持つ $\mathrm{N}$-結合型糖鎖 (化学的なエンジニアリング)を導入 することに成功した [Chem.Med.Chem.(2010) in press]。細胞 表層のリジン残基やホスファチジルエタノールアミン等の一 級アミンが過剩に存在する部分のみで選択的に反応が進行す 
not interfere the cell functions. This is the only available method which can label and/or engineer the cell-surfaces under such mild conditions and in very short time, out of the currently available chemical and biological protocols. Based on their method, the lymphocytes being extracted from the wild-type mouse, were labeled by the Cy5 with nearinfrared absorbance, and at the same time, engineered by the complex-type $\mathrm{N}$-glycan. The artificial lymphocytes were injected intravenously to the mouse tumor model in which DLD-1 human colon carcinoma was implanted to the dorsal division, and the non-invasive in vivo imaging was performed; the artificial cells not only trafficked to the spleen and the intestinal lymph nodes, but also accumulated in the tumor region [J. Carbohydr. Chem. (2010) in press]. They have found that the $\mathrm{N}$-glycan and its clusters, as well as the native lymphocytes did not target the tumor in vivo, and therefore, the data show that the both functions of the $\mathrm{N}$-glycan and the surfaces of the lymphocytes work synergistically to interact with the tumor cell; thus, a new strategy for cancer targeting was proposed from the fields of synthetic organic chemistry \& glycobiology.

As can be seen from these two examples, the newly developed bioconjugation chemistry in efficiently introducing the glycans on the proteins (or on the cell surfaces), might make important contributions to in vivo imaging and targeting in the future. Research at biology and chemistry interface will efficiently mimic and/or artificially create the glycan-based heterogeneous environments on the proteins and the surface of the cells, which lead to the efficient molecular imaging research in the glycan-related fields.

Reported by Katsunori Tanaka Department of Chemistry, Graduate School of Science, Osaka University

1-1 Machikaneyama, Toyonaka, Osaka 560-0043, Japan

ktzenori@chem.sci.osaka-u.ac.jp

FAX:06-6850-5419
るため、標識試薬が細胞内にインタナライズすることもなく、 細胞機能を阻害することはない。現在既存する化学的、また は生物学的標識化法の中で、細胞表層をこのような温和な条 件下、数分という短時間で標識や糖鎖でエンジニアリングで きる唯一の方法である。そこで、野生型マウスから抽出した リンパ球に対して、近赤外線領域付近の吸収を持つ Cy5 で蛍 光標識化すると同時に、 $\mathrm{N}$-結合型糖鎖で化学的にエンジニア リングした。ヒト由来の大腸癌細胞株である DLD-1 を移植し た癌モデルマウスに対してこの人工細胞を尾静脈から導入し、 非侵襲的なインビボイメージングを行ったところ、脾臓や腸 管膜リンパ節などの二次リンパ器官へのトラッキングに加え て、癌組織にも集積することが明らかにされた $[J$. Carbohydr. Chem. (2010) in press]。別実験において N- 結合型糖鎖やそのク ラスター、またはリンパ球自体は癌組織に集積しない結果を 得ており、N- 結合型糖鎖とリンパ球表層の両者の機能がリン パ球表層上で協調的に働いた結果である。このように、最新 の高速アザ電子環状反応を駆使して、有機合成化学分野と糖 鎖生物分野から、癌組織ターゲティングの新しいストラテジー を提起した。

以上述べてきたように、最新の有機合成反応を活用した夕 ンパク質や細胞表層への効率的な糖鎖導入が、今後インビボ イメージングやターゲティングの分野に扔いて重要な役割を 果たすことが伺えよう。生物学と化学による分野融合により、 タンパク質や細胞表層上に対して人工的に様々な糖鎖群、ま たは糖鎖と他の生体分子群によって構成される“不均一な糖 鎖生体分子社会” が効率的に構築され、糖鎖関連物質のイメー ジング研究が大いに発展することが期待される。

田中 克典

大阪大学大学院理学研究科 